\title{
Expect more from embryos
}

In Britain last month a domestic crisis over the disposition of frozen human embryos spilled over into Europe as governments and ethics committees debated the rights and wrongs of discarding thousands of embryos that had been kept frozen in liquid nitrogen for five years. The embryos (usually four- to eight-cell blastomeres) were created for the purposes of treating infertility, in clinics

\section{The controversy over fertilized cells has}

\section{overlooked research as a valuable option.}

for in vitro fertilization (IVF). The procedure typically involves inducing a woman to super-ovulate, collecting her eggs and fertilizing them in vitro with the sperm of her partner or a donor. Viable embryos are then selected, and whereas some are immediately implanted in the hope of generating a pregnancy, the majority are frozen in anticipation of future attempts at implantation.

But under a provision in the British Human Fertilization and Embryology Act of 1991, unclaimed cells would not be stored for more than five years. Now, the five years have passed, and throughout Britain, fertility clinics have been duly disposing of zygotes in cases in which the couples involved in the IVF treatment could not be located to consent to their disposal or continued storage.

Some people have been enraged, calling the disposal a "prenatal massacre" and a "national shame." One group of doctors in Italy went so far as to advocate the "adoption" of the zygotes by implantation in willing surrogate mothers.

In the United States, in vitro fertilization centers routinely (and quietly) dispose of unused zygotes unless the clinic has specific instructions to the contrary. For instance, some couples will allow donation to others who are not fertile; in some cases, the zygotes are used for research. But so far, there has not been the public outcry prompted by Britain's five-year rule.

Why not? One imagines that the issues are the same on both sides of the Atlantic. However, to do so ignores the strength of the "pro-life" lobby in the USA. For more than 20 years, sheer fear of antiabortion groups has played a decisive role in all US government decisions regarding federal funding of research that in any way touches on the beginnings of life. Not only is there no public funding for research involving human embryos, but the National Institutes of Health has been loath to fund even contraception research. As a consequence of the continual activity of antiabortion advocates, timid presidents (both Democratic and Republican) have promulgated various bans on human fetal tissue research and, indirectly, on related reproductive physiology. Despite carefully crafted documents from researchers, ethicists, and religious leaders who would regulate but not forbid such research, the White House has never yielded.

The result? Clinical investigation of infertility, and the development of such techniques as in vitro fertilization were, in a sense, forced into the private sector and out of government purview. Fertility clinics have as a consequence been free to try new approaches to assisted or in vitro conception without having to bother with the ethical review boards or other institutional sanctions that govern federally funded biomedical research. In effect, the government, through its research arm, has failed to acknowledge that in vitro fertilization even takes place. And it follows, as night does day, that there is no need for laws or review boards to govern an activity that is not recognized - the disposal of frozen zygotes that are not implanted in the women who donated the egg.

The United States has just emerged from carefully staged political conventions that avoided serious discussion of abortion. In this setting it seems impossible that the more demanding issues of embryo research will be reasonably discussed. Britain, too, has avoided many of the thorny issues. A cursory look at the British press reveals a debate hinging on a practical issue, with only a shallow consideration of the ethics involved. In the furor over the disposal of unclaimed embryos, it seems lost on most commentators that many couples whose embryos had been stored five years were successfully contacted and gave permission for disposal.

Headlines that ask whether unclaimed embryos should "die" imply a measure of humanness that only hard-line reductionists would apply to four-cell zygotes. These are not the well-recognized embryos that appear in books for expectant parents, yet that is precisely what we imagine. Rather, they are collections of a few cells with no prospect for life without the most extreme intervention. That is not to say that this material should be treated the same way as any other cells. Careful consideration must be given to embryo generation, storage, use and disposal. Even though it is reasonable to limit the length of time unclaimed embryonal tissue can be stored, it would be even more intelligent to permit the use of these unwanted cells in ways that would advance infertility research, as well as the study of developmental biology and neuroscience. Is it too much to imagine that more embryo research might lead to improvement in IVF procedures and, as a consequence, a need for fewer embryos? - Barbara J. Culliton and Adrian J. Ivinson 